Historic, Archive Document

Do not assume content reflects current scientific knowledge, policies, or practices. 
1.96

A2.ECI

EC-1

insew

iorsecticides

for

Gccushopper

Coorteol

(ain

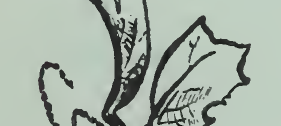

s?

$1 \times 15$

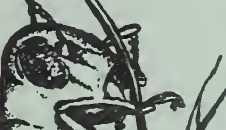

3

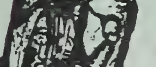

- $50=0$



$3 \div$

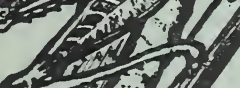

政

,

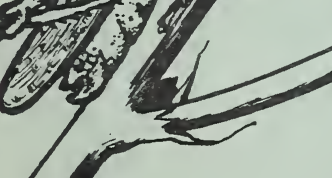

\section{BUREAU OF} ENTOMOLOGY and

PLANT QUARANTINE AGRICULTURAL RESEARCH ADMINISTRATION U.S. DEPT. of AGRICULTURE 
This publication was prepared by J. R. Parker, of the Division of Cereal and Forage Insect Investigations, and Claude Wakeland, of the Division of Grasshopper Control. 
Many farmers are now using spreys or dusts containing new insecticides insterd of broadoasting bren-sawdust-s odium fluosillcate bait for grasshopper control. Of the rarious new chemicals tested, chlordane and chlorinated camphene have shown the most promise. Under certain conditions they are more effective than bait. There now insectioldes are finding faror because they kill more rapidly and give better control of grasshoppers in tall, succulent growth along roadsides, railroad rights-ofway, canal banks, pield margins, and in alfalfa. Chlordane and chlorinated camphene are most effective wen applied to succulent regetation were grasshoppers are feeding heavily. On bare ground, dry stubble, or in tall, dry regetation which is no longer attractire to grasshoppers as food, balt is generally more effective and eco nomical.

Insectioldes containing chlordane or benzene hexachloride have been id dely used for grasshopper control, both as dusts and as sprays. Those containing chlorinated camphene have not been 80 generally arallable, but comparative tests by the Bureau of Intomology and Plant Quarantine in 1947 showed them to be as effective as those containing chlordane. The results obtained with benzene hexachloride, al though generally good, have been more rariable.

When these new insectioides are applied as dusts or sprays directly to succulent growth along field margins, or to crops such as rank-growing alfalfa, young cotton, llax, or corn, they give quicker control and continue to kill longer than the standard sodium fluosolicate bait, wich has been in general use for grasshopper control in recent years. The period of effectireness ranges from 1 to 3 weeks, depending upon the weathor, the amount and type of regetation, the season, the age of 
the Erasshoppers, and to some extent on the particular formulation of the chemical used. Sprays and dusts containing these new chemicals have not been found more effective than the standard bran-sawdust-sodium-fluom silicate balt for controlling grasshoppers on range, idle lands, in small grains, or in field margins where vegetation is sparse.

\section{Dosages and Formulations}

Research has shown that chlordane and chlorinated camphene give higher initial kill, and continue to kill over a longer period, when applied as sprays than when equal dosages are applied as dusts. When using sprays, apply 1 pound of technical chlordane or $1 \frac{1}{2}$ pounds of technical chlorinated camphene per acre. Then using dusts, apply $1 \frac{1}{2}$ pounds of technical chlordane or 2 pounds of chlorinated camphene per acre. Late in the season, when most of the grasshoppers are adults and vegetation is tall and dense, a slight increase in the dosage of both sprays and dust may be necessary.

Chlordane and chlorinated camphene are marketed as emulsion concentrates, wettable powders, and dusts of rarious strengths. Imulsion concentrates and wettable powders may be diluted with water to suit arailable spraying equipment, but whatever the formulation or dilution the quantity of the technical material applied per acre should conform to the recommendations given.

\section{Time and Methods of Application}

As is true of bait, these new insecticides must be properly applied at the right time, and in the right places, if they are to be effective. Likewise, as in the use of bait, it is much better for 211 property owmers in a community to apply them at the sane time. These new materials may be applied with ground dusters or sprayers of various types or from airplanes. However, 
the equipment used should be carefully ad justed 80 that the rate of application may be acourately controlled. The insecticide should be evenly distributed over the area needing treatrent. The use of too much material is not only wasteful but increases the danger of residues; the use of too little wastes labor and meterials and does not prevent crop losses.

To farmers who intend to use one of these new inseoticides for trasshopper oontrol, the following advice is offered:

1. Remember that they, like most insecticides, are poisonous to man and livestock. Observe proper precautions in handing them and aroid feeding live stock on forage or pasture to which any of them has been applied.

2. Determine the location of dangerous infestations of young grasshoppers in relation to your crop lands. They may be found on roadsides, canal banks, field margins, or idle lands bordering cultivated fields, as well as in the fields themselves. Spray or dust these infestations when the main batch is completed or hen the young hoppers begin to move of 1 the hatching grounds, and thus greatly reduce the acreage to be treated. Grasshoppers that damage row crops generally hatch in the field margins, where with timely baiting, dusting, or spraying they may be destroyed before they more into the fields.

3. To prevent grasshoppers from damaging corn, treat mergins of cornfields and adjacent infested small-grain fields or weed patches when small grains begin to mature and before the hoppers more into the corn.

4. When an entire alfalfa field is infested with damaing populations of grasshoppers, it is ordinarily more eco nomical to cut the alfalfa and then apply control measures to protect the next 
cutting. The best procedure is to spray or dust field margins, ditch banks, patches of weeds, or uncut strips of alfalfa where grasshoppers bare concentrated after the first crop is removed. Crasshoppers frequently batoh in considerable numbers after the first crop has been harrested and fields have been irrigated. These insects can be controlled by spraying or dusting the next crop when the regetation is 6 to 10 inches high. By this practice heary insecticide residues on this crop at harvestilime may be aroided and material damage to the new growth prevented unless other grasshoppers migrato into the field.

\section{Precautions}

Forage treated with these new insecticldes should not be fed to dairy animals. Stockmen should not feed treated regetation to animals that are being fattened for slaughter.

$\triangle$ related ohlorinated compound is known to accumulate in the fatty tissues of animals and is giten off in milk and butter. It is therefore possible that chlordane or chlorinated camphene behave similarly. Forage treated with these insecticides at dosages heavier than those needed for grasshopper control has been fed to meat animals continuously, and to the exclusion of any other feed, for sereral weeks without visable impairment of their health or derelopment. It is possible, howerer, that meat animals fod for long periods on treated forage might accumulate enough of these chemicals in their fatty tissues to make the meat unfit for food.

Do not apply chlordane or chlorinated camphene to fruits or leafy regetables when foliage or fruit that is to be used as food is on the plant, unless the residue can and will be removed by washing or stripping. 
Lroid applying these new insecticides to legumes when in bloom or at the times of day when bees are actire in the field.

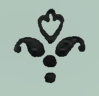



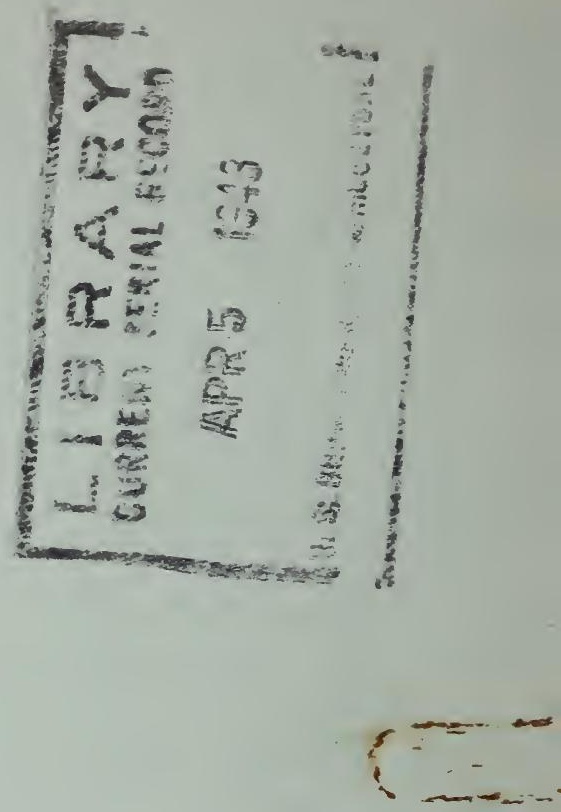